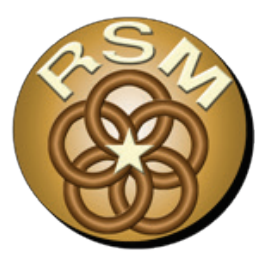

\title{
Understanding Regional Shoreline Change and Coastal Processes at the Sunset Beach Region, Oahu, Hawaii
}

\author{
by Thomas D. Smith, Jessica H. Podoski, Zeki Demirbilek, \\ and Lihwa Lin
}

PURPOSE: This U.S. Army Corps of Engineers (USACE) Regional Sediment Management Technical Note (RSM-TN) reviews the development of a conceptual understanding of the complex regional coastal sediment processes at the Sunset Beach region on the island of Oahu, HI, which is a component of the USACE Hawaii Regional Sediment Management investigations. This document discusses the numerical modeling and volume change rate methodology used to identify sediment pathways in the region. This conceptual understanding of the sediment processes for the Sunset Beach region was developed to help inform future sediment management planning and decisions and to aid in identification of potential RSM actions within the region.

BACKGROUND: Regional Sediment Management (RSM) refers to the effective use of littoral, estuarine, and riverine sediment resources in an environmentally sensitive and economically efficient manner. RSM was officially implemented at the U.S. Army Engineer District, Honolulu (POH), in February 2004. The POH overall RSM plan is to investigate RSM opportunities along all regions in Hawaii. Conceptual regional sediment budgets have been developed in various regions throughout the islands to gain a general understanding of the control that morphology and coastal processes have on sediment pathways and transport volumes.

The POH RSM focus in Fiscal Year 2015 was the Sunset Beach region (Figure 1). Figure 2 shows the reaches that comprise the region. From west to east, these reaches are Reach 1 (Kulalua Point to Rocky Point), Reach 2 (Rocky Point to Sunset Point), and Reach 3 (Sunset Point to Velzyland). There are no federally authorized coastal flood risk management or navigation projects located within the region.

APPROACH: Shoreline change for the region was quantified by the U.S. Geological Survey (USGS) in its report titled National Assessment of Shoreline Change: Historical Shoreline Change in the Hawaiian Islands (USGS 2012). POH conducted additional shoreline change analysis using the USGS shorelines. U.S. Army Engineer Research and Development Center (ERDC) Coastal Modeling System numerical models CMS-Wave and CMS-Flow (Demirbilek and Rosati 2011) were implemented to simulate wave transformation and water circulation within the region. Prevailing wind (tradewind) and predominant wave (northwest) conditions were simulated in steering mode to capture the interdependence of waves and currents. In addition, analysis using flow path visualizations identified dominant sediment pathways. Results from the shoreline change analysis and coastal processes modeling were utilized to develop a conceptual understanding of the complex sediment dynamics at the Sunset Beach region. 
ERDC/TN RSM-18-1

January 2018

\section{Shoreline Change Analysis}

U.S. Geological Survey (USGS). Shoreline change rates were calculated by the USGS (2012) from long-term and short-term shoreline data. USGS used all available shorelines (approximately 11 shorelines since 1910) for long-term rate calculations. Post-World War II shorelines were used for short-term rate calculations.

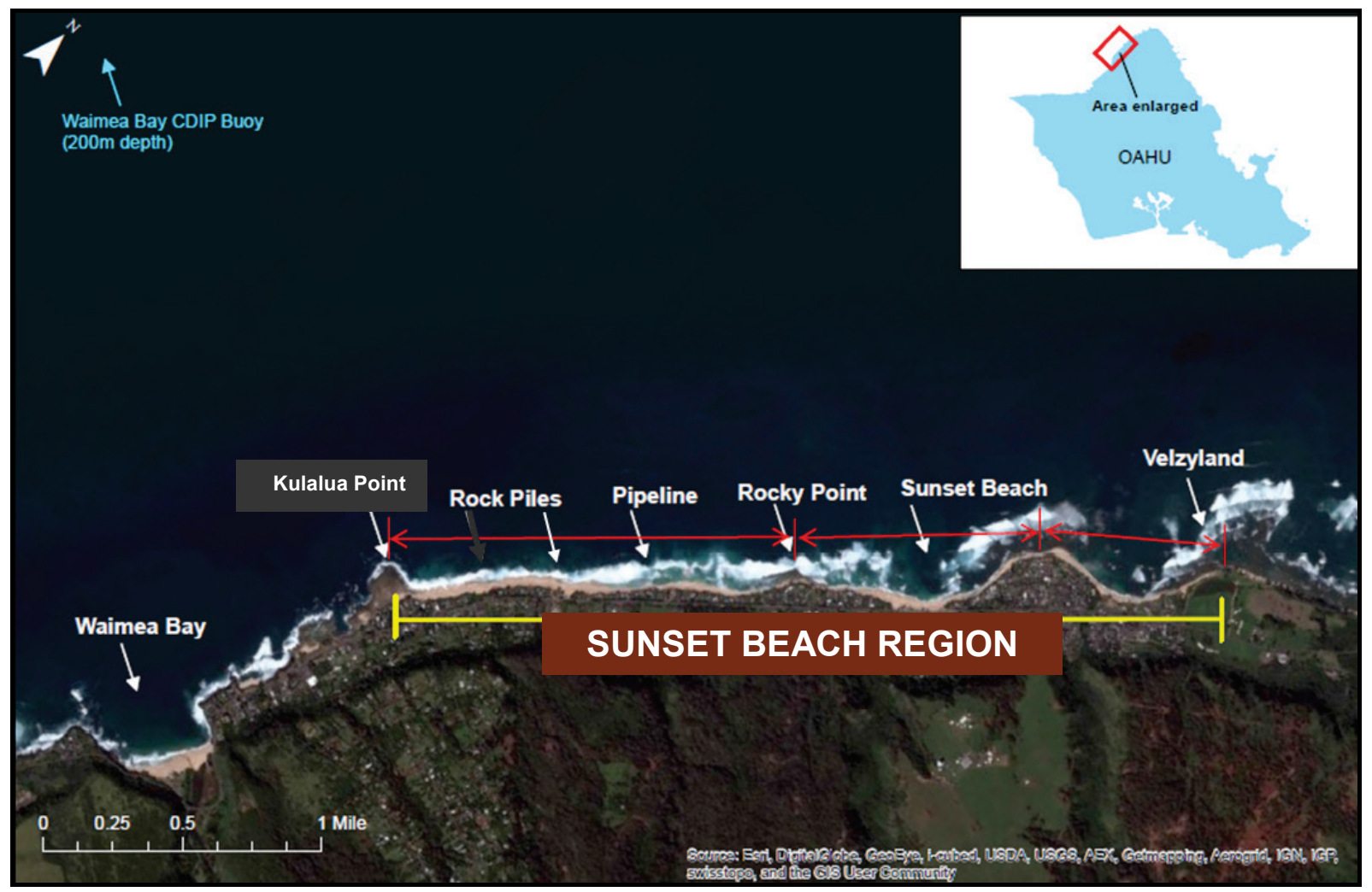

Figure 1. Location map of the Sunset Beach RSM region, Oahu, HI.

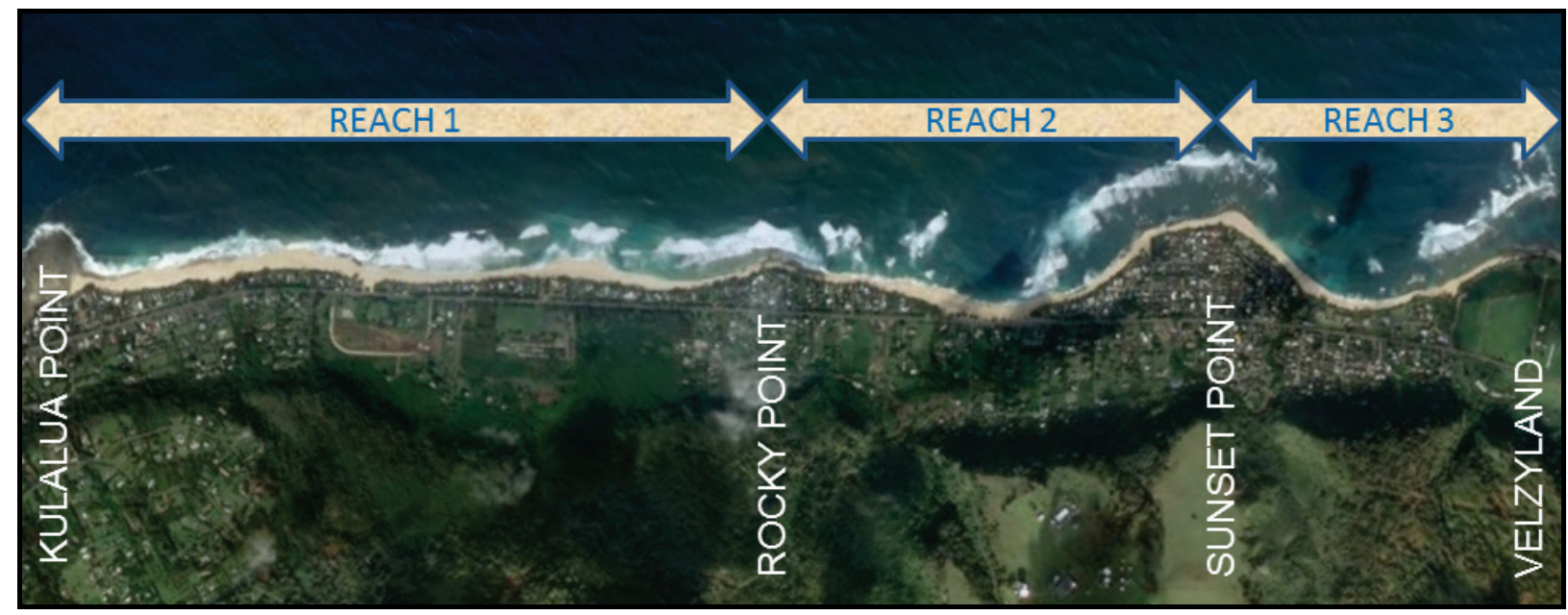

Figure 2. Map of the reaches that comprise the Sunset Beach region. 
A minimum of three historical shoreline positions was required when calculating a shoreline change rate with the technique employed by the USGS. In summary of its findings, the average long- and short-term rates on the north shore are erosional at $-0.36 \pm 0.03$ feet per year (ft/yr) and $-0.23 \pm 0.03 \mathrm{ft} / \mathrm{yr}$, respectively. Seventy-three percent $(73 \%)$ of the total extent of North Oahu shorelines are eroding in the long term, and 68\% are eroding in the short term. The USGS (2012) study provides the best available data on shoreline change for the north shore. However, the report notes that erosion rates at some north shore beaches are unreliable as a result of high seasonal variability and/or poor seasonal distribution of the available aerial photographs.

Honolulu District (POH). POH utilized the USGS shorelines to conduct additional shoreline change analysis for the Sunset Beach region. USGS measured the distance from the toe of the beach to an offshore baseline along 270 transects in the Sunset Beach region to define shoreline positions for the available photogrammetric datasets. Figure 3 displays USGS beach toe distances (from west to east) for 7 different years from 1949 to 2006 . USGS shoreline distances from 1928, 1933, and 1961 were not used in the analysis due to their source of origin, positional inaccuracies, and/or limited extent.

Figure 3 shows the dynamic and seasonal nature of the region's shoreline change. In the winter months, large swell with directions ranging from west-northwest through northeast result in an overall steep and narrow beach profile. During the summer months, the beach generally becomes wider with a milder sloped beach profile. However, some beach segments on the north shore are known to gain sand in winter months and erode in summer months due to localized wave and current patterns. Reach 1 exhibits the greatest seasonal variation in shoreline location, evidenced by up to $292 \mathrm{ft}$ of variability at Transect 64. The western portion of Reach 2 (Transect 117 to Transect 150) is also quite variable with shoreline recession recently threatening upland development. The remainder of Reach 2 is relatively stable. Reach 3 is the most stable reach in the region with variability of shoreline positions of under $50 \mathrm{ft}$ over the period of analysis.

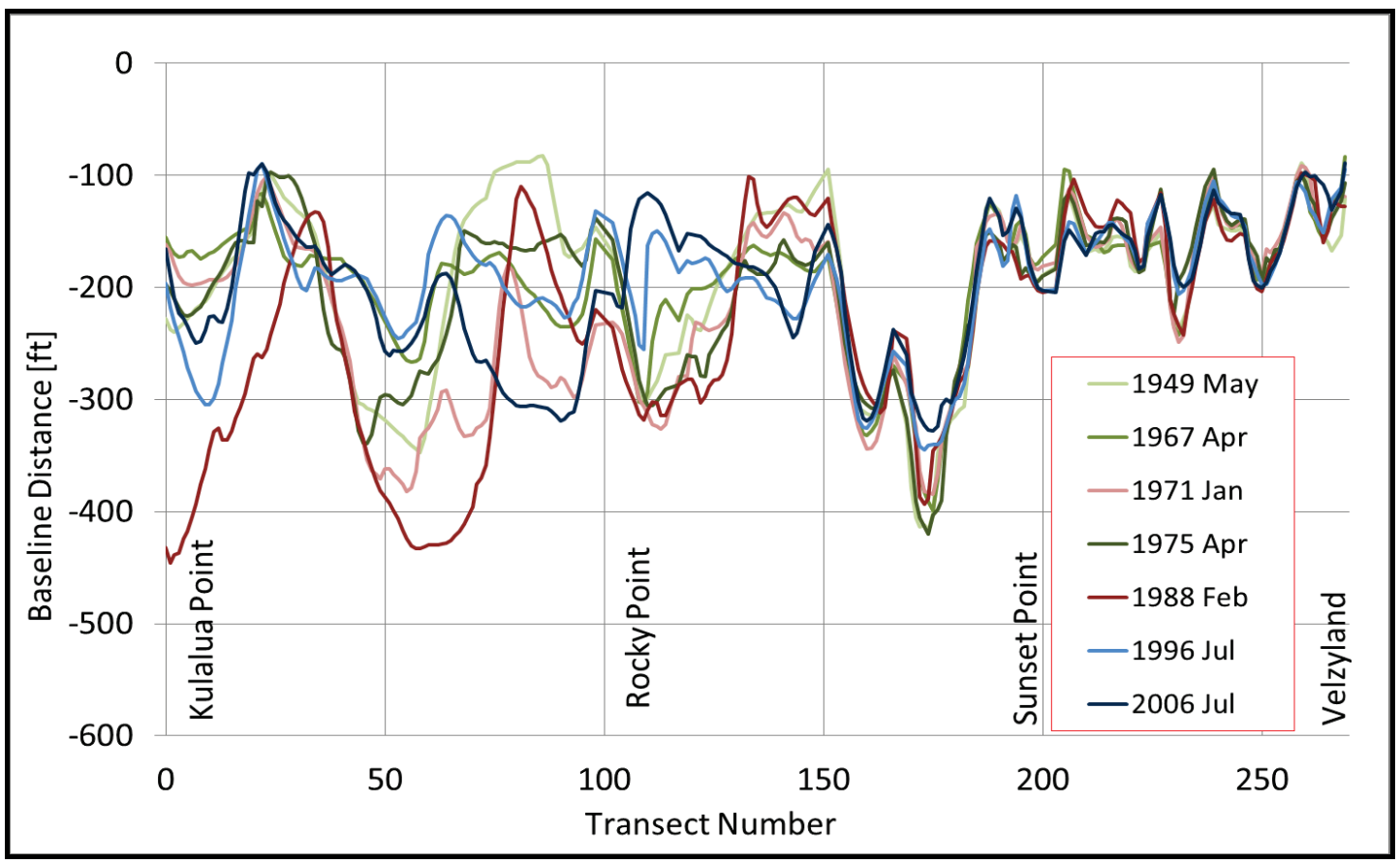

Figure 3. Shoreline distances within the Sunset Beach region from 1949 to 2006. 
To estimate the quantity of sand represented in the shoreline changes reported by the USGS, $\mathrm{POH}$ utilized a conversion value of 0.4 cubic yard (cy) of sand per square foot (sq $\mathrm{ft}$ ) of beach based on guidance provided by the Coastal Engineering Manual (USACE 2002). Assuming that as an unarmored beach erodes it maintains approximately the same profile above the seaward limit of significant transport. This conversion value of $0.4 \mathrm{cy} / \mathrm{sq} \mathrm{ft}$ has been developed by $\mathrm{POH}$ for Hawaii study areas where there is limited profile data. Figure 4 displays the volume change rate represented by the USGS shoreline change dataset for various time periods between 1949 and 2006 at each transect. The most dynamic area was in Reach 1 between Transect 40 and Transect 80. From 1967 to 1971 , there was erosion of -16.3 cy/year (yr) at Transect 46 . In contrast, there was accretion of $+17.3 \mathrm{cy} / \mathrm{yr}$ at Transect 68 during the period from 1971 to 1975 . Transects 46 and 68 are denoted in Figure 4 by a green triangle and a red triangle, respectively. A long-term volume change rate (thick blue line), calculated from the entire period of analysis (1949 to 2006), extends along the origin of the graph.

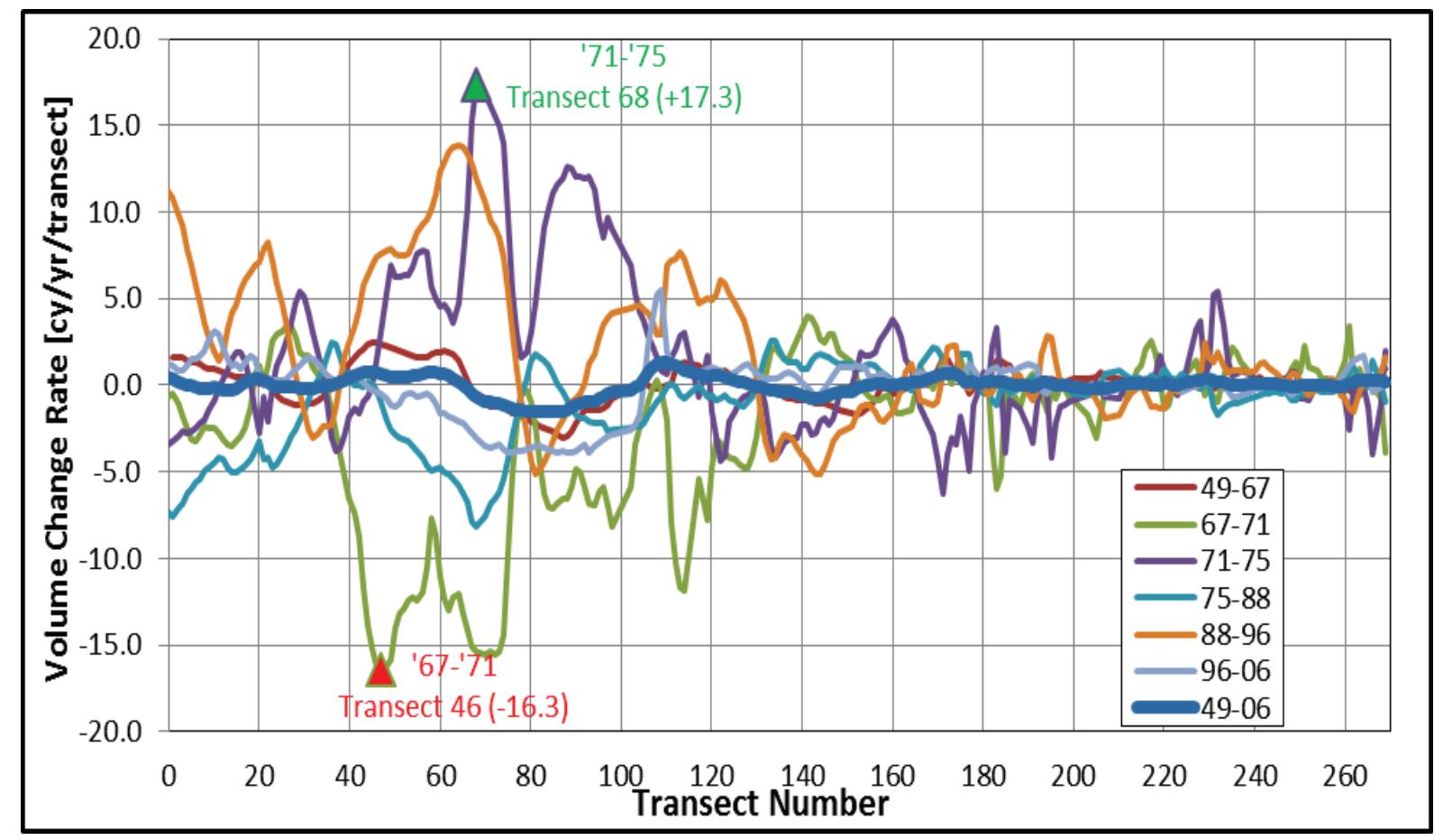

Figure 4. Volume change at each transect (cy/year/transect) for the various time periods in the available shoreline dataset.

Figure 5 displays just the results from Figure 4 for the volume change rate at each transect during a 57 yr period from 1949 through 2006. As previously mentioned, these rates are small compared to the values for the various successive time intervals shown in Figure 4. The highest rate of accretion was seen at Transect $110(+1.3 \mathrm{cy} / \mathrm{yr})$ while Transect 86 saw the highest rate of erosion $(-1.6 \mathrm{cy} / \mathrm{yr})$. The seasonality exhibited in the year-to-year rates is not apparent when comparing the changes that occurred over the entire $57 \mathrm{yr}$ period of analysis. Since the shoreline has been shown to be relatively stable over the entire region during the time period considered, areas of sediment storage offshore of the beach toe must exist. Empirical evidence indicates that sediment is stored in channels perpendicular to shore and probably in shoals on the reef platform during the winter months because sediment returns to the beach during summer months. Seasonal longshore transport of sand over the subaerial beach is also significant. 


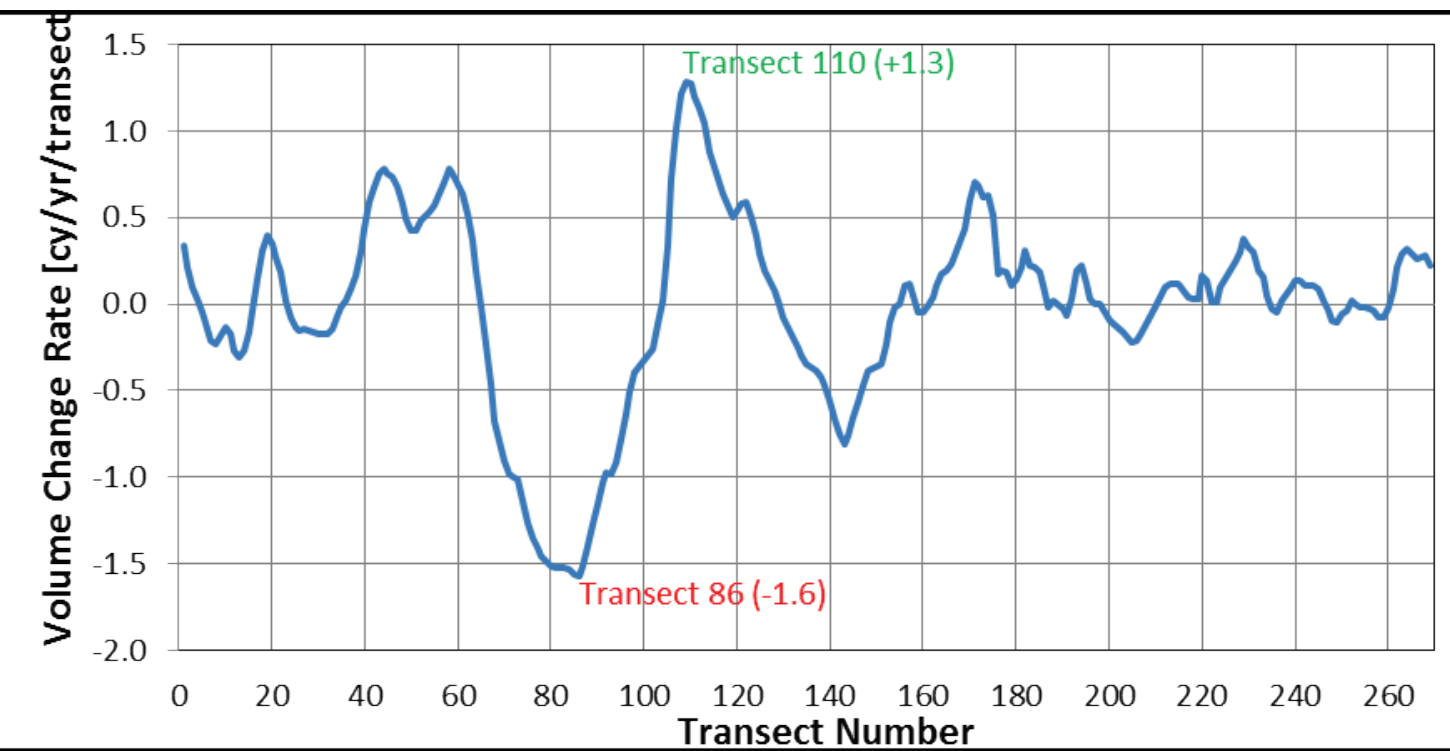

Figure 5. Volume change rates at each transect over the entire $57 \mathrm{yr}$ period of analysis (1949 through 2006).

Cumulative volume changes for the various time intervals between 1949 and 2006 are shown in Figure 6. The greatest increase in beach volume of $+275,000$ cy occurred for the time period 1988 through 1996. Note that the 1988 shoreline was from February (winter) and the 1996 was from July (summer). This does not skew the results because differences in winter and summer volumes blend with the entire 8 yr time period.

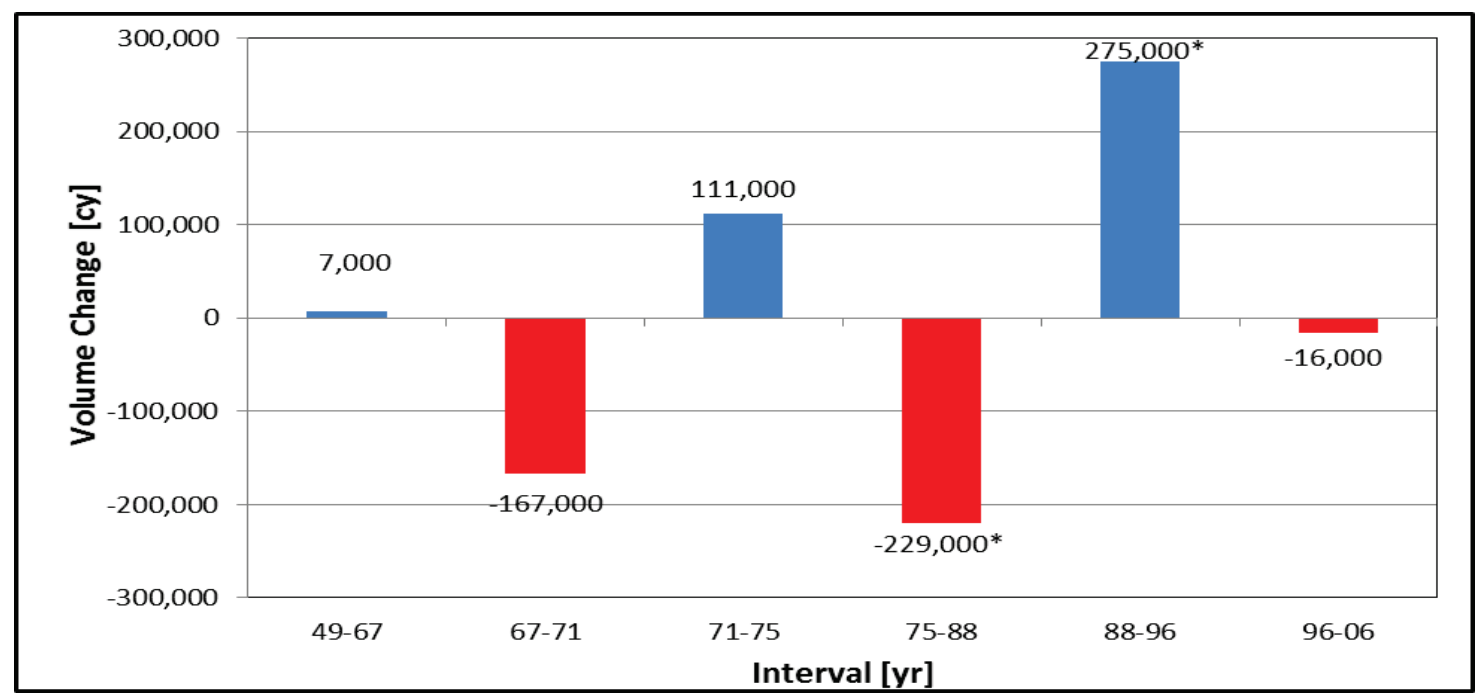

Figure 6. Volume changes for various time periods based on USGS (2012) shoreline change data.

The greatest decrease in beach volume of -229,359 cy occurred between 1975 and 1988. In this case, the 1975 data represent a summer profile (April) while as previously noted, the 1998 was acquired in the winter (February). For two shorelines taken in the summer but separated by 10 years (July 1996 and July 2006), the change in beach volume was only $-16,000 \mathrm{cy}$. This agrees 
with the overall beach volume change between 1949 and 2006 of $-19,000$ cy. It is therefore suggested that in the Sunset Beach region, a stable beach volume has been maintained over the time period 1949 through 2006. Possible redistribution of sediment throughout the region is investigated in the following section of this RSM-TN.

Development of the understanding of the complex regional coastal sediment processes at the Sunset Beach region was based on shoreline changes during the $31 \mathrm{yr}$ period between 1975 and 2006. Figure 7 displays baseline distances for the four available shorelines during this period (12 April 1975, 2 February 1988, 9 July 1996, and 20 July 2006). The figure also contains the 2015 vegetation line to put into context the criticality of past shoreline change with respect to a common frame of reference. To illustrate this point, it can be seen that the 1975 shoreline receded landward to within a few feet of the vegetation line at Transect 170. As indicated previously, Reach 1 experiences the largest variation in shoreline position along with the western portion of Reach 2. The shoreline in the eastern portion of Reach 2, and all of Reach 3, has remained relatively stable over the period of analysis.

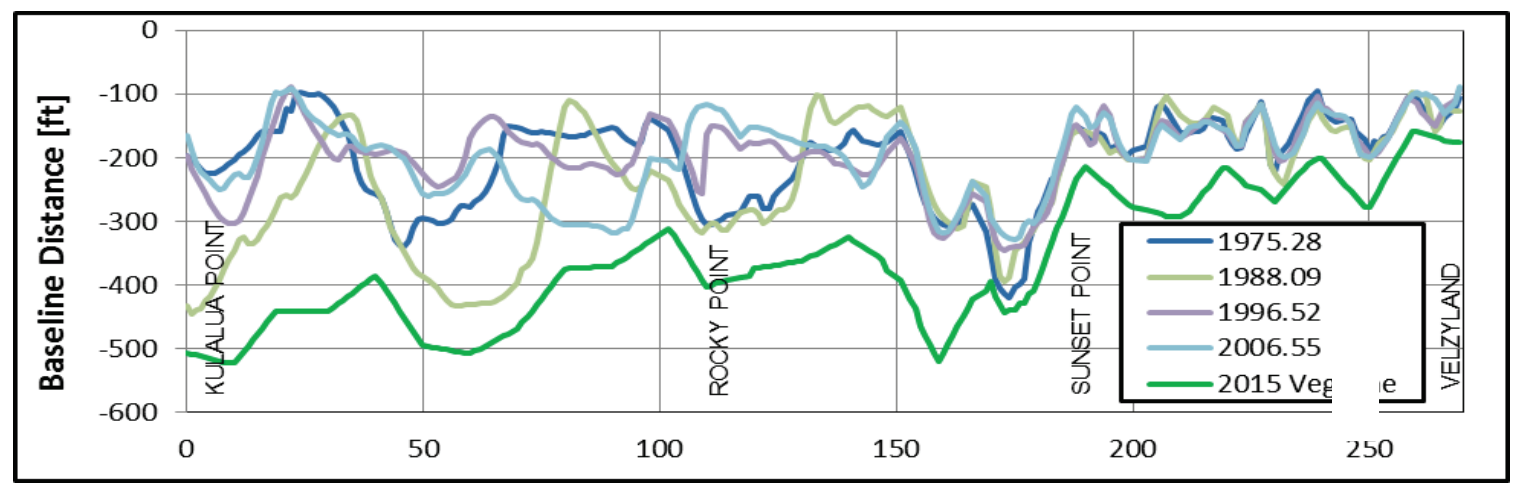

Figure 7. Shoreline (beach toe) distances within the Sunset Beach region from 1975 to 2006. Also shown is the vegetation line as surveyed via GPS in January 2015. The vertical axis is the distance from an arbitrary offshore baseline (measurement location).

To further investigate the shoreline variability in the Sunset Beach region, the limits of the landward and seaward excursion of the shoreline between 1975 and 2006 were identified (Figure 8). The trend of large variations in shoreline position with time along the western half of the region (Transect 1 through Transect 150) is evident in Figure 8. In contrast, the extremes in landward and seaward shoreline movement are relatively small to the east (Transect 151 through Transect 269). Figure 9 contains the same information but only shows the absolute difference in extreme shoreline position at each transect for the period 1975 through 2006. The largest shoreline excursion was $292 \mathrm{ft}$ at Transect 64 (denoted by a red triangle in Figure 9) while the distances decreased to the east to near zero. 


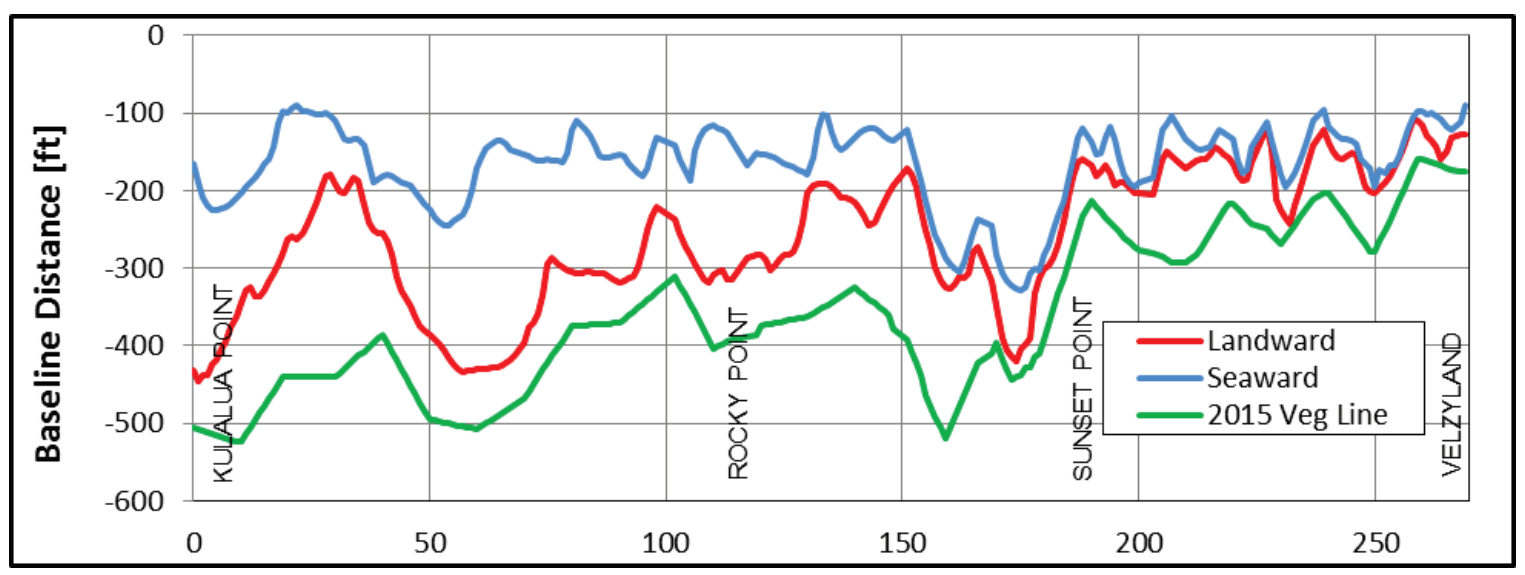

Figure 8. Landward and seaward excursions of shoreline position for the years 1975 through 2006. Also shown is the vegetation line distance as surveyed via GPS in January 2015. The vertical axis is the distance from an arbitrary offshore baseline (measurement location).

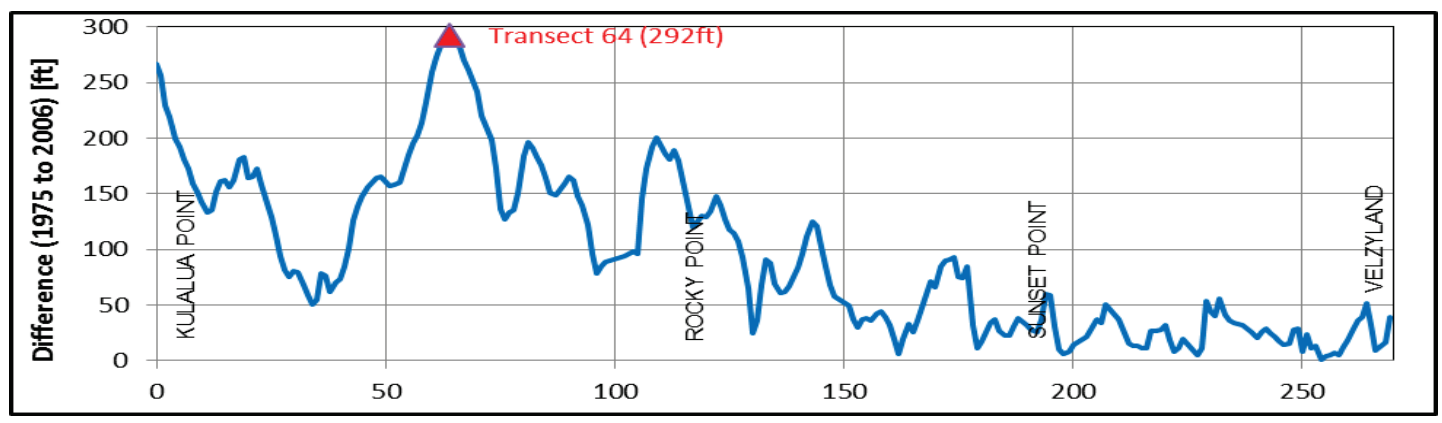

Figure 9. Difference (feet) of the landward and seaward excursions of shoreline (beach toe) position for the years 1975 through 2006.

Numerical Modeling. An understanding of the sediment transport processes for the Sunset Beach region requires evaluation of waves and circulation in the region. A wave and flow modeling study was implemented to infer regional sediment transport patterns in this very complex and dynamic coastal region. The regional processes influencing the region's shoreline that were considered in setting up the numerical model are complex and include the following:

- multi-directional wave climate

- complex nearshore bathymetry including coral reefs

- relic stream channels that influence nearshore flow

- northeast trade winds occurring throughout the year.

CMS-Wave and CMS-Flow models (Demirbilek and Rosati 2011) were used to develop estimates of waves and currents. Grid bathymetry for the wave and current models was created using the island-wide bathymetry dataset maintained by the University of Hawaii, School of Ocean and Earth Science and Technology, Department of Ocean and Resources Engineering (Figure 10(a), note depths are in meters). A spatially varying friction factor was applied to both CMS-Wave and CMS-Flow to incorporate the effects of increased friction over nearshore reefs on currents and wave breaking, shown in Figure 10(b). Historical wave data were provided by the USACE Wave Information Study (WIS) hindcast database and the Coastal Data Information 
Program's (CDIP) Waimea Bay buoy. The location of the Waimea Bay buoy is shown in Figure 11, and the wave period and wave height roses for the period 1 September 2013 through 30 April 2015 are displayed in Figure 12. The CMS-Wave model was calibrated using wave data from nearshore (approximately $5 \mathrm{ft}$ depth) and offshore (approximately $58 \mathrm{ft}$ depth) wave gages deployed in the region in 2009.
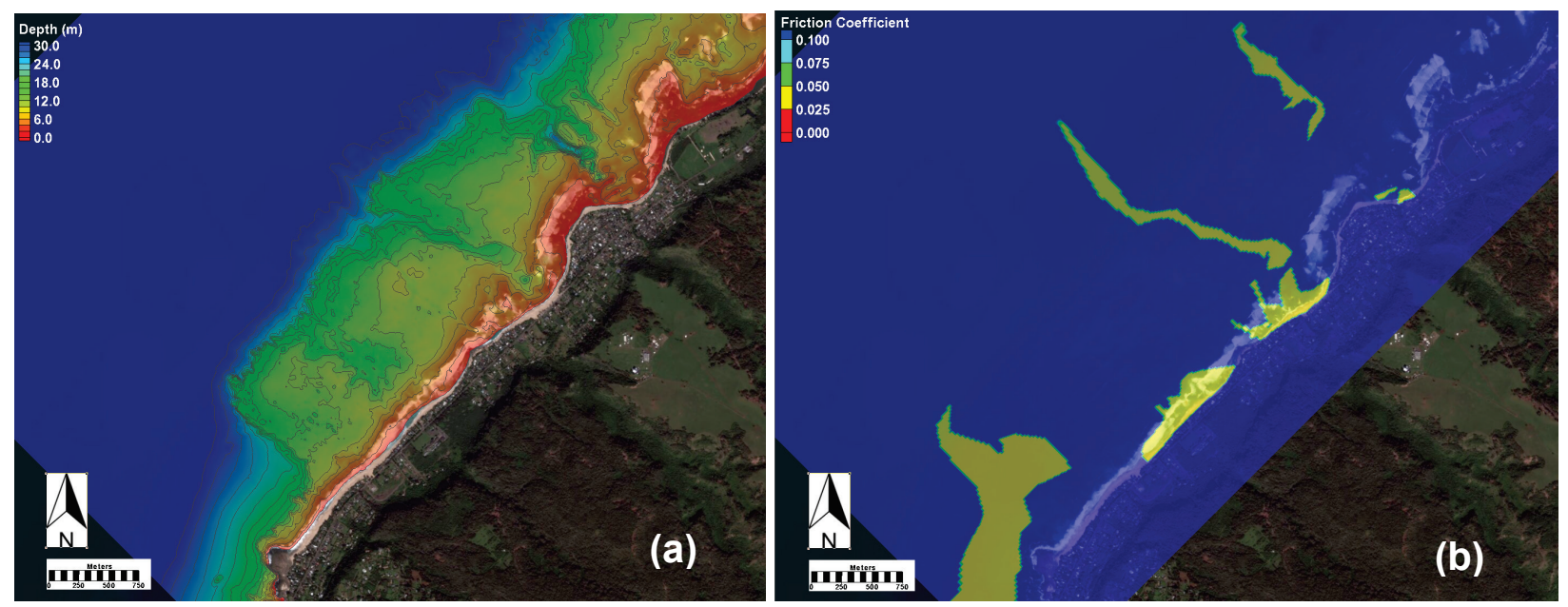

Figure 10. (a) Sunset Beach region bathymetry and (b) spatially varying friction coefficient.

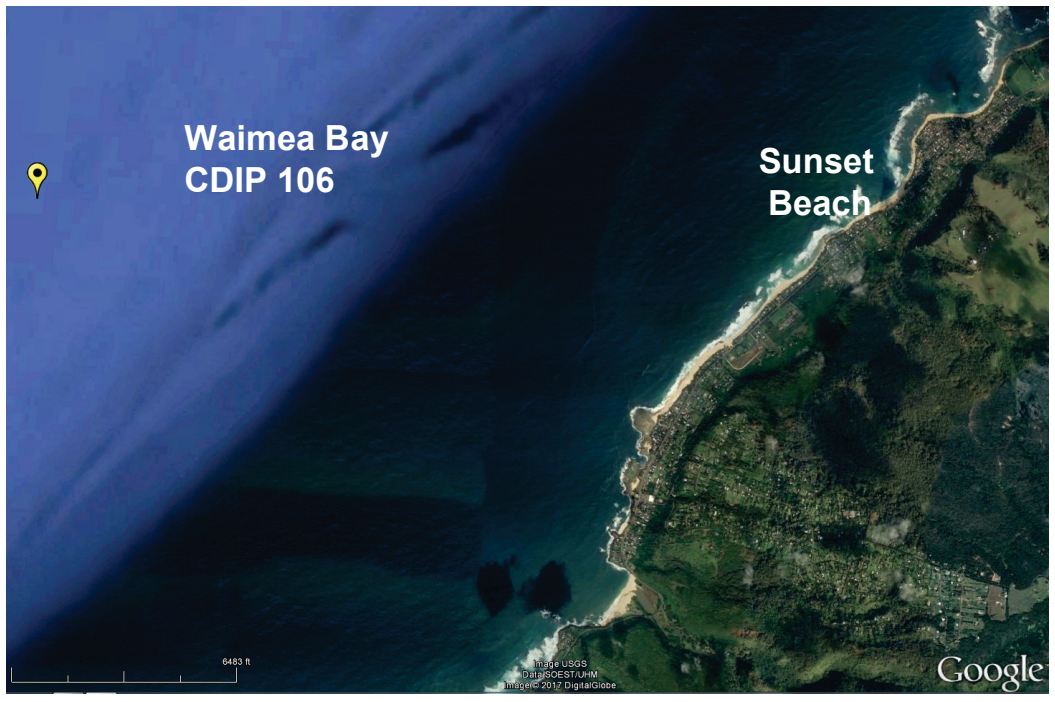

Figure 11. Map showing the location of the Coastal Data Information Program's Waimea buoy (from Google Earth https://www.google.com/earth/). 

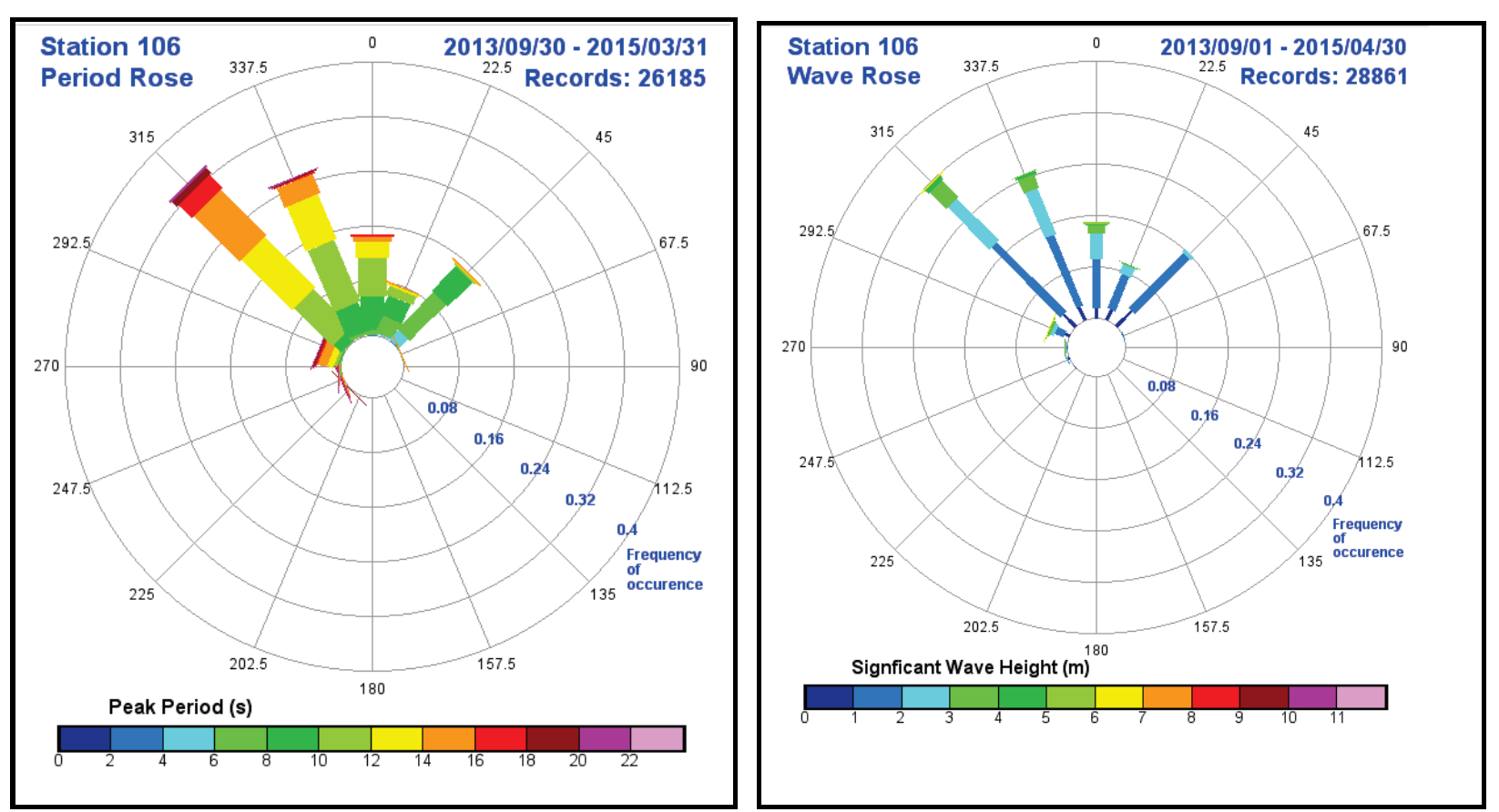

Figure 12. Peak wave period and significant wave height roses for CDIP Station 106 from 1 September 2013 through 30 April 2015.

Figure 13 provides a snapshot of the circulation patterns that develop during a northwest swell (deepwater wave height $=13.5 \mathrm{ft}$; peak wave period $=20$ seconds $[\mathrm{sec}]$; and wave direction $=$ 302 degrees [deg]). The CMS-Flow trace feature enables visualization of the strong currents that dominate sediment transport at Pipeline, Rocky Point, and Sunset Beach. At Pipeline, the model reproduces the well-known strong (approximately $2.5 \mathrm{ft} / \mathrm{sec}$ ) easterly nearshore current that develops just offshore of the beach toe. The large circulation cell east of Pipeline directs flow alongshore and seaward through Ehukai Channel. Two smaller circulation cells develop east of Rocky Point, with a seaward flow through a shallow channel on the east side of Rocky Point. The strongest flow that develops in the region during a northwest swell appears to be directed out of the Sunset Beach channel.

A tradewind condition was also modeled (deepwater wave height $=5.25 \mathrm{ft}$; peak wave period $=$ $9 \mathrm{sec}$; and wave direction $=48 \mathrm{deg}$ ) to better understand the prevailing condition for the region. Although the current magnitudes for the tradewind condition were not as dramatic as those for large northwest swell, it is understood that large volumes of sand are gradually transported westerly over this longer-duration condition.

SUNSET BEACH REGION SEDIMENT PROCESSES: The results of the wave/circulation model steering runs and the subsequent visualizations, in combination with the shoreline change analysis, were used to inform development of an understanding of the complex dynamic coastal sediment processes at the Sunset Beach region for the time period 1975 through 2006. It was determined by the POH RSM project delivery team that the Sunset Beach region is too dynamic to establish a reliable sediment budget within the limits of this investigation. Future work will be proposed for further study, and subsequent development of a regional sediment budget for the Sunset Beach region. 


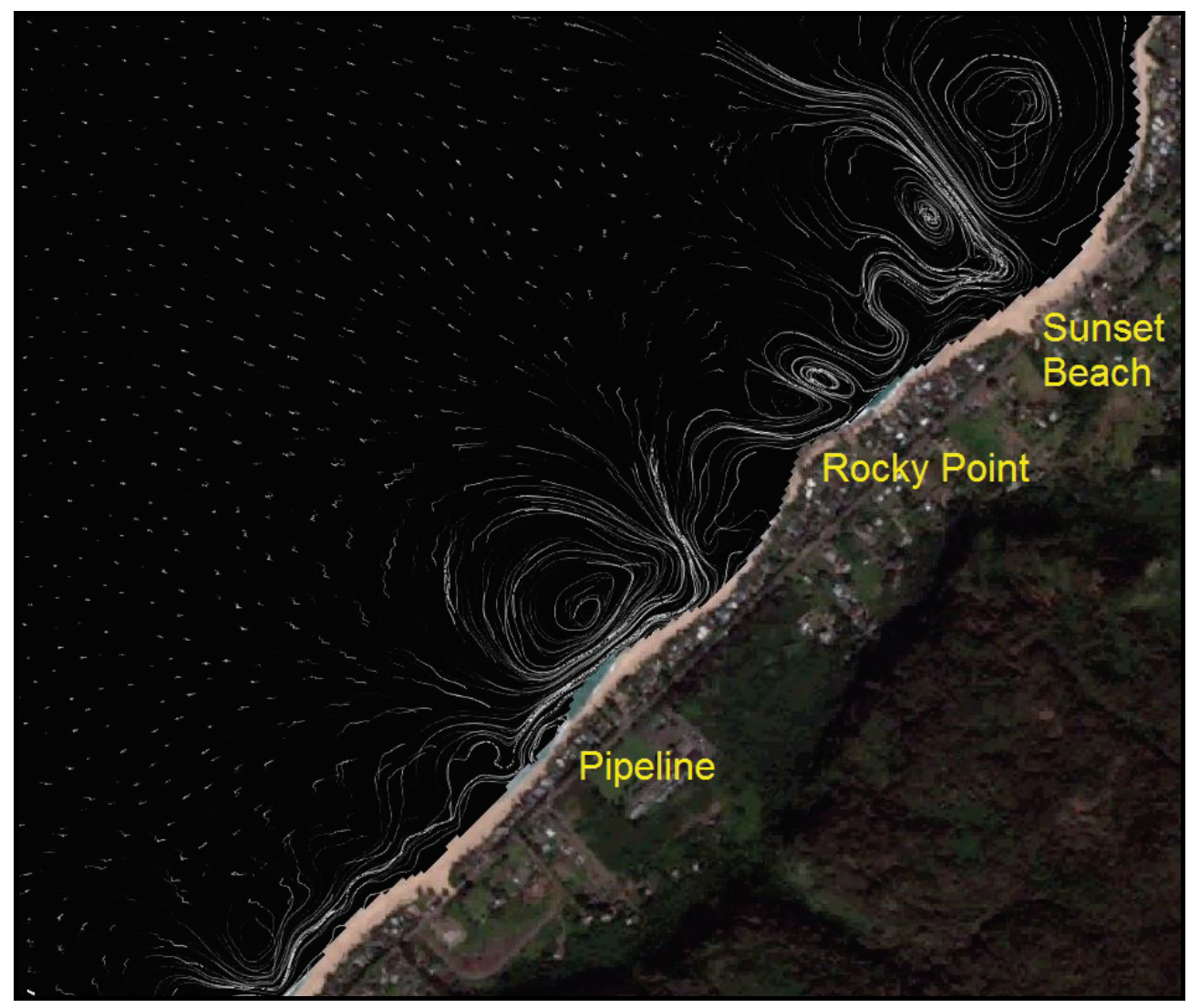

Figure 13. CMS-Flow Trace visualization indicating major circulation patterns at Pipeline, Rocky Point, and Sunset Beach (from Google Earth https://www.google.com/earth/).

CONCLUSIONS: The analysis of shoreline change completed by the USGS (2012), as well as numerical modeling of waves, currents, and sediment pathways by $\mathrm{POH}$, has aided in an increased understanding of the coastal processes at work along the Sunset Beach region shoreline of Oahu, HI. Overall, the dynamics of the area are very complex, with a wave climate affected by intricate bathymetry, wind, and varying coastal morphology. In addition, uncertainties with the USGS (2012) shoreline data and this analysis are high due to high seasonal variability. Current and wave models indicate that large and episodic wave events in the winter direct sediment transport to the east. In the summer, gentle but consistent tradewinds generate waves and currents that redirect the sediment back to the west. This results in high volumes of seasonal sediment transport, though there appear to be small values of net long-term transport of sediment. There is also evidence of nearshore eddy formation due to coastal morphology that, in combination with quickly changing wave conditions, increases the complexity of sediment transport in the region. In summary, this is a very dynamic and seasonally affected shoreline, and the RSM investigations completed here are one tool that will help inform future shoreline management in the region.

POINTS OF CONTACT: This Regional Sediment Management Technical Note (RSM-TN) was prepared as part of the USACE Hawaii RSM Program and was written by Thomas D. Smith, U.S. Army Corps of Engineers, Honolulu District (POH), Honolulu, HI, with input from the Hawaii RSM Product Delivery Team. Additional information pertaining to Hawaii RSM can be 
found at http://gis.poh.usace.army.mil/rsm/index.htm. Additional information regarding the USACE National RSM Program may be obtained at http://rsm.usace.army.mil.

Questions regarding this RSM-TN may be addressed to Thomas D. Smith, Thomas.D.Smith@usace.army.mil (Hawaii RSM POC). Questions pertaining to the National RSM Program may be addressed to the USACE National RSM Program Manager, Linda Lillycrop, Linda.S.Lillycrop@usace.army.mil. This ERDC/TN RSM-18-1 should be cited as follows:

Smith, T. D., J. H. Podoski, Z. Demirbilek, and L. Lin. 2018. Understanding Regional Shoreline Change and Coastal Processes at the Sunset Beach Region, Oahu, Hawaii. ERDC/TN RSM-18-1. Vicksburg, MS: U.S. Army Engineer Research and Development Center. http://dx.doi.org/10.21079/11681/26285

\section{REFERENCES}

Demirbilek, Z., and J. D. Rosati. 2011. Verification and Validation of the Coastal Modeling System: Report 1; Summary Report. ERDC/CHL TR-11-10. Vicksburg, MS: U.S. Army Engineer Research and Development Center. http://hdl.handle.net/11681/7660.

U.S. Geological Survey (USGS). 2012. Charles H. Fletcher, Bradley M. Romine, Ayesha S. Genz, Matthew M. Barbee, Matthew Dyer, Tiffany R. Anderson, S. Chyn Lim, Sean Vitousek, Christopher Bochicchio, and Bruce M. Richmond. National Assessment of Shoreline Change: Historical Shoreline Change in the Hawaiian Islands. Open-File Report 2011-1051. Reston, VA: U.S. Geological Survey. http://pubs.usgs.gov/of/2011/1051.

U.S. Army Corps of Engineers (USACE). 2002. Coastal Engineering Manual: Part III, Coastal Sediment Processes; Chapter 3, Cross-Shore Sediment Transport Processes. EM 1110-2-1100.Washington, DC: U.S. Army Corps of Engineers. http://www.publications.usace.army.mil/USACEPublications/EngineerManuals/u43544q/636F617374616C20656E67696E656572696E67206D616E75616C/.

NOTE: The contents of this technical note are not to be used for advertising, publication, or promotional purposes. Citation of trade names does not constitute an official endorsement or approval of the use of such products. 